\title{
The Effect of Ketone Bodies and Fatty Acid on Intestinal Glucose Metabolism during Development
}

\author{
ROBERT E. KIMURA, GUNILLA THULIN, AND JOSEPH B. WARSHAW \\ Department of Pediatrics, University of Utah School of Medicine, Salt Lake City, Utah, USA
}

\section{Summary}

Glucose oxidation by developing rat intestine changed dramatically during the period of suckling and weaning. After weaning, glucose oxidation to $\mathrm{CO}_{2}$ by intestinal slices increased over 3 fold. This was associated with an increase in lactate production from glucose and an increase in the rate of pyruvate decarboxylation.

Active pyruvate dehydrogenase in intestine of developing rats also increases in activity at the time of weaning, suggesting that the suppression of glucose oxidation during the suckling period is controlled by pyruvate dehydrogenase. Glucose oxidation to $\mathrm{CO}_{2}$ and pyruvate decarboxylation to $\mathrm{CO}_{2}$ by intestinal slices of postweaned animals was inhibited by exogenous 3-hydroxybutyrate. But exogenous 3-hydroxybutyrate did not inhibit glucose and pyruvate oxidation in intestine of suckling animals which have higher levels of endogenous 3-hydroxybutyrate than intestine of postweaned rats. Palmitate, in contrast, inhibited glucose and pyruvate oxidation by both pre- and postweaned intestine.

\section{Abbreviations}

DTT, dithiothreitol

KRP, Krebs Ringer phosphate

In the small intestine, substrates are not only delivered by the blood but are also immediately available from intraluminal absorption. Changes in the diet that occur during suckling and weaning have been shown to alter intracellular fatty acid levels in intestinal mucosal cells. The suckling rat pup diet consists of a high percentage of lipid (approximately $70 \%$ of total caloric content) (6). During suckling, the level of free fatty acids in serum is markedly elevated as compared with adult levels (23) and the intracellular levels of esterified fatty acids in jejunal mucosal cells are increased (3). At the time of weaning the rat pup's diet changes to one that is predominantly carbohydrate and the concentration of free fatty acids in the serum and the levels of esterified fatty acids in the mucosal cells decrease to that found in the adult. An increase in liver ketogenesis during the suckling periods results in an increase in serum ketone levels. Page et al. (20) determined that serum 3-hydroxybutyrate concentrations of suckling rat are 3 -fold greater than weaning pups and 6-fold greater than adults.

These abrupt changes in serum and intracellular concentrations of free and esterified fatty acids and ketone bodies provide a natural perturbation of influences on glucose metabolism. Srivastav and Hubscher (21) reported that glycolysis and hexokinase activities in rat intestine are increased at the time of weaning relative to activity in suckling pups. Hahn and Skala (7) reported increases in glucose-6-phosphate dehydrogenase and pyruvate kinase activities at the time of weaning in rat intestine and Hulsmann (12), using perfused adult rat intestine, showed that when fatty acids are present in the perfusate, $\mathrm{CO}_{2}$ production from glucose was markedly decreased and lactate production increased. In the present study we investigated developmental change in glucose metabolism to $\mathrm{CO}_{2}$, lactate, and pyruvate by intestine during the time of suckling and weaning.

\section{MATERIALS AND METHODS}

Rat mothers with litters were obtained from Charles River Laboratory (27). The pups were artificially weaned at $21 \mathrm{~d}$ of age to Ralston Purina Rodent Lab Chow 5001 which consists of $4.5 \%$ fat. The animals were killed by decapitation. After the intestines were removed, they were flushed with ice cold KRP $\mathrm{pH} 7.4$, slit lengthwise, and placed in KRP. Intestinal slices of $0.5 \mathrm{~mm}$ thickness were prepared with Mcllwain tissue chopper (28). Slices were blotted dry, weighed, and placed into $10-\mathrm{ml}$ Erlenmeyer flasks containing $1 \mathrm{ml}$ of KRP and substrate (ice cold). Twenty-five to fifty milligrams of tissue was used unless otherwise designated in the test. The substrates used in these experiments $(30)$ were $5 \mathrm{mM}$ glucose containing [UL $-{ }^{14} \mathrm{C}$ ]glucose with a final specific activity of $0.16 \mathrm{Ci} / \mathrm{mol},\left[1-{ }^{14} \mathrm{C}\right]$ glucose and $\left[6-{ }^{14} \mathrm{C}\right]$ glucose with a final specific activity of $0.1 \mathrm{Ci} / \mathrm{mol}$, and pyruvate $(1 \mathrm{mM}$ and $20 \mathrm{mM})$ containing $\left[1-{ }^{14} \mathrm{C}\right] \mathrm{Na}$-pyruvate with a final specific activity of $0.12 \mathrm{Ci} / \mathrm{mol}$ for the $1 \mathrm{mM}$ solution and $0.03 \mathrm{Ci} / \mathrm{mol}$ for the $20 \mathrm{mM}$ solution. Five millimolars glucose was found to give an optimal rate of glucose oxidation. The optimal concentration for pyruvate oxidation was $10 \mathrm{mM}$.

The metabolic flasks were sealed in the presence of room air with rubber caps which were fitted with polypropylene center wells (Kontes Glass Co.) (29). Because the rate of $\mathrm{CO}_{2}$ and lactate production from glucose was constant for the incubation period, it can be assumed that aerobic conditions were present. The flasks were removed from ice and the reaction was started by placing the flasks in a shaking water bath at $37^{\circ} \mathrm{C}$. The reactions were terminated by cooling on ice and adding $1 \mathrm{ml}$ of $10 \%$ perchloric acid. Incubation time was $60 \mathrm{~min}$ when $5 \mathrm{mM}$ glucose and $20 \mathrm{mM}$ pyruvate were substrates and $30 \mathrm{~min}$ when $1 \mathrm{mM}$ pyruvate was used. Hyamine hydroxide, $0.3 \mathrm{ml}$, was injected through the rubber caps into the polypropylene center well to absorb $\mathrm{CO}_{2}$ and the flasks were incubated another $45 \mathrm{~min}$ at $37^{\circ} \mathrm{C}$. The hyamine hydroxide was removed to counting vials containing $5 \mathrm{ml}$ of Econofluor (30) for measuring radioactivity in a liquid scintillation counter $(31)$. In order to determine $\left[{ }^{14} \mathrm{C}\right]$ lactate produced from $\left[1-{ }^{14} \mathrm{C}\right]$ glucose and $\left[6-{ }^{14} \mathrm{C}\right]$ glucose, $\left[{ }^{14} \mathrm{C}\right]$ glucose was removed from remaining assay solution by the method of Barker and Summerson (1) and the remaining $\left[{ }^{14} \mathrm{C}\right]$ was measured. We assume that the majority of $\left[{ }^{14} \mathrm{C}\right]$ from glucose is either in the form of glucose, $\mathrm{CO}_{2}$, or lactate.

We used a tissue slice technique rather than homogenates so that endogenous pools of substrate and metabolic controls which are present at the time of animal sacrifice are left intact. A number of criticisms of the tissue slice technique have been raised, including nonuniform diffusion of substrates. This is less of a problem in intestine in which mucosal cells, primarily villous 
cells are present on the villi as a monolayer so that substrate access to these cells is likely to be uniform. Another possible source of error is the presence of endogenous pools of substrate which could dilute the isotopes which we used in our assay. Since our assays were linear over an extended time interval (30-60 $\mathrm{min}$ ) the dilutional effect of endogenous pools on specific activities of the isotopes used in the assay systems must be minimal.

For determination of pyruvate dehydrogenase activity in whole intestinal homogenates, intestines were removed and immediately placed in liquid nitrogen after pups were sacrificed by decapitation. The intestines were then weighed and crushed while still frozen. They were then homogenized in a buffer of $10 \mathrm{mM}$ $\mathrm{KH}_{2} \mathrm{PO}_{4}, 1 \mathrm{mM}$ DTT, $1 \%$ EDTA, $12.5 \mathrm{mM} \mathrm{NaF}, 10 \%$ ethanol (pH 7.4) with a final concentration of $50 \mathrm{mg}$ of tissue $/ \mathrm{mI}$ of buffer. The homogenate was frozen in liquid nitrogen. After approximately $30 \mathrm{~min}$, the homogenate was thawed on ice and assayed for pyruvate dehydrogenase activity using the method described by Taylor et al. (22) with the exception that a final assay volume of $0.6 \mathrm{ml}$ was used. In order to determine total pyruvate dehydrogenase activity, intestine was homogenized and preincubated in an activating solution of $10 \mathrm{mM} \mathrm{KH_{2 }} \mathrm{PO}_{4}, 1$ $\mathrm{mM} \mathrm{DTT}, 1 \%$ bovine serum albumin and $15 \mathrm{mM} \mathrm{MgCl}_{2}$ for 20 min at $30^{\circ} \mathrm{C}$. $\mathrm{NaF}$ and ethanol were then added with final concentration of $12.5 \mathrm{mM}$ and $10 \%$, respectively, and the solution was then frozen in liquid nitrogen and assayed for pyruvate dehydrogenase activity.

The amount of endogenous 3-hydroxybutyrate and acetoacetate in intestine was determined on samples of intestine frozen in liquid nitrogen. Intestine was homogenized using a Brinkman Polytron in $6 \mathrm{~N} \mathrm{HClO}_{4}$. The protein precipitate was removed by centrifugation and the resulting supernatant was neutralized with $\mathrm{KOH}$. The potassium perchloric precipitate was removed and 3hydroxybutyrate and acetoacetate was determined fluorometrically using the method described by Williamson and Corkey (24).

To determine the rate of production of lactate, tissue was incubated in $5 \mathrm{mM}$ glucose in $\mathrm{KRP}$ at $37^{\circ} \mathrm{C}$ in a shaking water bath for $10 \mathrm{~min}$. After the reaction was terminated by the addition of perchloric acid, lactate (11) was determined on a neutralized solution using spectrophotometric methods. Tissues were weighed on a Sauter AR-70 balance. The $t$ test for independent variables was utilized to calculate statistical significance.

\section{RESULTS}

Changes in glucose oxidation to $\mathrm{CO}_{2}$ and lactate in developing rat intestine. The rate of glucose oxidation to $\mathrm{CO}_{2}$ by intestinal slices of rats from $16 \mathrm{~d}$ of age to adult is shown in Figure 1. During the suckling period (16 d of age) the rate of glucose oxidation is low compared with postweaning activity. During the weaning period (18-21 d) and immediately after artificially induced weaning $(21 \mathrm{~d})$ there is an abrupt increase in glucose oxidation which peaks at $23 \mathrm{~d}$ of age. Glucose oxidation subsequently decreased to adult levels which remained higher than activity seen during the suckling period.

Lactate production, which has been used as an index of glycolytic activity (21), increased from a prewean rate of $1.62 \pm$ $0.08($ mean $\pm S E M)$ nmol lactate produced per $g$ wet wt per min to a postwean rate of $2.73 \pm 0.10$, which is significant $(P<$ $0.001)$. Adult values $(1.93 \pm 0.13)$ were similar to those found in the suckling animals.

$\left[{ }^{14} \mathrm{CO}_{2}\right]$ production from $\left[1-{ }^{14} \mathrm{C}\right]$ glucose and $\left[6-{ }^{14} \mathrm{C}\right]$ glucose by developing rat intestine was determined to give an indication of changes in the source of $\mathrm{CO}_{2}$ production (Table 1). $\left[{ }^{14} \mathrm{CO}_{2}\right]$ production from $\left[1-{ }^{14} \mathrm{C}\right]$ glucose increased 2 -fold after weaning. In contrast, $\left[{ }^{14} \mathrm{CO}_{2}\right]$ production from $\left[6-{ }^{14} \mathrm{C}\right]$ glucose increased 5fold. Before weaning, the ratio of $\left[{ }^{14} \mathrm{CO}_{2}\right]$ production from [1$\left.{ }^{14} \mathrm{C}\right]$ glucose to $\left[{ }^{14} \mathrm{CO}_{2}\right]$ from $\left[6-{ }^{14} \mathrm{C}\right]$ glucose was 2.07 compared with 1.16 postweaning. This indicates a greater increase in $\mathrm{CO}_{2}$ production from the glycolytic-pyruvate oxidation pathway com-

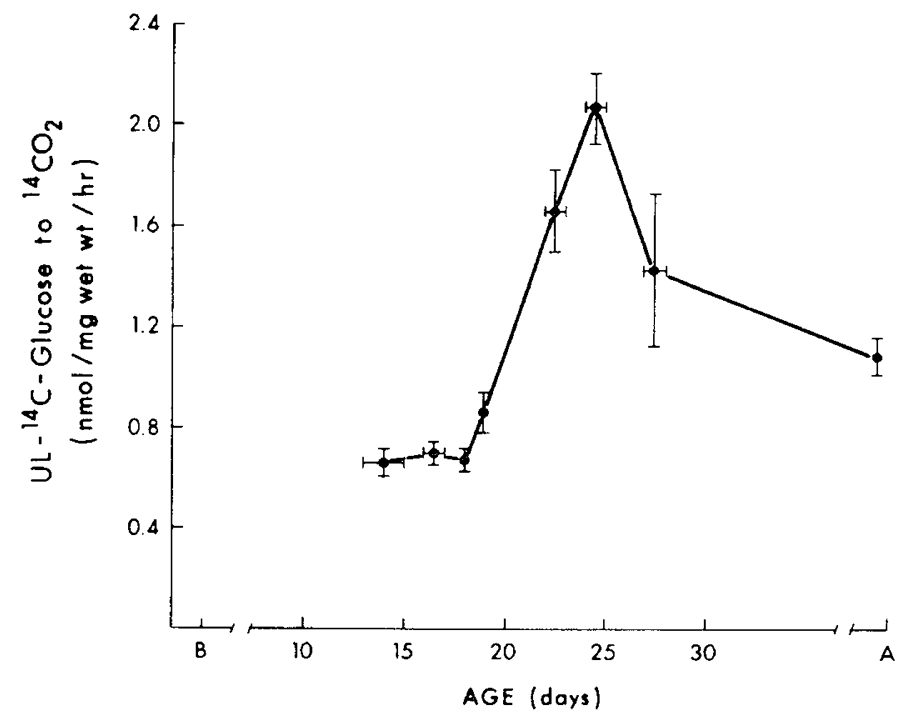

Fig. 1. Developmental profile of $\left[\mathrm{UL}-{ }^{14} \mathrm{C}\right] \mathrm{glucose}$ oxidation to $\left[{ }^{14} \mathrm{CO}_{2}\right]$ by rat small intestinal tissue slices.

pared with the hexosemonophosphate pathway at the time of weaning.

The oxidation of $\left[1-{ }^{14} \mathrm{C}\right]$ glucose and $\left[6-{ }^{14} \mathrm{C}\right]$ glucose to $\left[{ }^{14} \mathrm{C}\right]$ lactate was also determined (Table 2). In both pre- and postweaned rat intestine, the ratio of $\left[{ }^{14} \mathrm{C}\right]$ lactate from $\left[1-{ }^{14} \mathrm{C}\right]$ glucose to $\left[{ }^{14} \mathrm{C}\right]$ lactate from $\left[6-{ }^{14} \mathrm{C}\right]$ glucose was approximately 1 . The ratios of $\left[{ }^{14} \mathrm{C}\right]$ lactate to ${ }^{14} \mathrm{CO}_{2}$ production from both $\left[1-{ }^{14} \mathrm{C}\right]$ glucose and $\left[6-{ }^{14} \mathrm{C}\right]$ glucose were greater than 18 for both pre- and postweaned rats (Table 1).

Pyruvate dehydrogenase activity in developing intestine. In order to determine if the abrupt increase in glucose oxidation to $\mathrm{CO}_{2}$ at the time of weaning is mediated by pyruvate dehydrogenase activity, we measured pyruvate dehydrogenase in the active form, total pyruvate dehydrogenase activity, and the rate of pyruvate decarboxylation by intestinal tissue slices (Table 2). There is a 6 -fold increase in the active form of pyruvate dehydrogenase activity at the time of weaning. The increase in pyruvate dehydrogenase activity appears to be secondary to both an increase in the total amount of pyruvate dehydrogenase (2-fold increase at the time of weaning) and a 3-fold increase in the percentage of pyruvate dehydrogenase in the active form. Using a 1-mM concentration of exogenous pyruvate, the rate of decarboxylation of $\left[1-{ }^{14} \mathrm{C}\right]$ pyruvate to $\left[{ }^{14} \mathrm{CO}_{2}\right]$ also increased at the time of weaning (Table 3).

In order to determine a possible mechanism for the increase in the percentage of active pyruvate dehydrogenase in intestine from postweaned pups, we determined the ratio of mitochondrial $\left[\mathrm{NAD}^{+}\right] /[\mathrm{NADH}]$ indirectly by determining tissue levels of $3-$ hydroxybutyrate and acetoacetate. In heart $(8,15)$, it has been established that an increased $\left[\mathrm{NAD}^{+}\right] /[\mathrm{NADH}]$ ratio results in an increase in the active form by pyruvate dehydrogenase. The tissue concentration of 3-hydroxybutyrate during the suckling period is 10 -fold greater than levels measured in postweaned intestine $(280 \pm 34 \mathrm{nmol} / \mathrm{g}$ wet wt of tissue). The concentration of acetoacetate was only $50 \%$ greater in the tissue from suckling animals $(65 \pm 7.3)$ compared with those postweaned $(42.5 \pm$ $2.5)$. Because the ratio of 3 -hydroxybutyrate to acetoacetate decreases 8-fold at the time of weaning, (4.47 to 0.54$)$ the estimated intramitochondrial $\left[\mathrm{NAD}^{+}\right] /[\mathrm{NADH}]$ ratio increases 8-fold (the ratio of 3-hydroxybutyrate to acetoacetate is inversely proportional to $\left[\mathrm{NAD}^{+}\right] /[\mathrm{NADH}]$ ratio).

The effect of 3-hydroxybutyrate and palmitate on glucose and pyruvate metabolism by developing rat intestine. Suckling rats have elevated serum concentrations of free fatty acids and ketone bodies $(20,23)$. The levels of endogenous 3-hydroxybutyrate in 
Table 1. Oxidation to $\left[1-{ }^{14} \mathrm{C}\right] g l u c o s e$ and $\left[6-{ }^{14} \mathrm{C}\right] g l u c o s e$ to $\mathrm{CO}_{2}$ and lactate by developing rat intestine*

\begin{tabular}{|c|c|c|c|c|c|}
\hline Age & Products & {$\left[1-{ }^{14} \mathrm{C}\right]$ glucose oxidation } & {$\left[6-{ }^{14} \mathrm{C}\right]$ glucose oxidation } & $\frac{\mathrm{CO}_{2}(1-\mathrm{C})}{\mathrm{CO}_{2}(6-\mathrm{C})}$ & $\frac{\text { Lactate }(1-C)}{\text { Lactate }(6-C)}$ \\
\hline \multirow[t]{2}{*}{$16 \mathrm{~d}$} & ${ }^{14} \mathrm{CO}_{2}$ & $\begin{array}{c}0.87 \pm 0.07 \\
(18)\end{array}$ & $\begin{array}{c}0.42 \pm 0.04 \\
(18)\end{array}$ & 2.07 & \\
\hline & Lactate & $\begin{array}{c}25.7 \pm 1.4 \\
(17)\end{array}$ & $\begin{array}{c}25.3 \pm 1.4 \\
(17)\end{array}$ & & 1.01 \\
\hline \multirow[t]{2}{*}{$23 \mathrm{~d}$} & ${ }^{14} \mathrm{CO}_{2}$ & $\begin{array}{c}2.24 \pm 0.10 \dagger \\
(6)\end{array}$ & $\begin{array}{c}1.93 \pm 0.04 \uparrow \\
(6)\end{array}$ & 1.16 & \\
\hline & Lactate & $\begin{array}{c}37.2 \pm 0.7 \dagger \\
(6)\end{array}$ & $\begin{array}{c}35.8 \pm 1.2 \dagger \\
(6)\end{array}$ & & 1.04 \\
\hline \multirow[t]{2}{*}{ Adult } & ${ }^{14} \mathrm{CO}_{2}$ & $1.19 \pm 0.06 \dagger$ & $\begin{array}{c}0.79 \pm 0.05 \dagger \\
(5)\end{array}$ & 1.51 & \\
\hline & Lactate & $\begin{array}{c}25.0 \pm 0.7 \\
(5)\end{array}$ & $26.7 \pm 1.2$ & & 0.94 \\
\hline
\end{tabular}

* Data are expressed as nmol glucose oxidized $\cdot \mathrm{mg}$ wet $\mathrm{wt}^{-1} \cdot \mathrm{h}^{-1}$. Values expressed as mean $\pm \mathrm{SE}$ (number of experiments).

$\uparrow$ Value significantly different from 16 -d-old $(P<0.01)$.

Table 2. Pyruvate dehydrogenase activity by developing rat intestine*

\begin{tabular}{crcc}
\hline Age $(\mathrm{d})$ & \multicolumn{1}{c}{$\mathrm{PDH}_{\mathrm{A}} \dagger$} & $\mathrm{PDH}_{\mathrm{T}} \neq$ & \% Active \\
\hline $16 \mathrm{~d}$ & $65.4 \pm 15.3$ & $274 \pm 38.7$ & 12.9 \\
$23 \mathrm{~d}$ & $426.2 \pm 31.2$ & $559 \pm 27.5$ & 76.0 \\
\hline
\end{tabular}

${ }^{*}$ Data expressed as nmol $\left[1-{ }^{14} \mathrm{C}\right]$ pyruvate decarboxylated to ${ }^{14} \mathrm{CO}_{2} \cdot \mathrm{g}$ tissue $\mathrm{e}^{-1} \cdot \mathrm{min}^{-1}$. Values expressed as mean $\pm \mathrm{SE}$ of five animals.

$\dagger \mathrm{PDH}_{\mathrm{A}}$, the active form of pyruvate dehydrogenase.

$\ddagger \mathrm{PDH}_{\mathrm{T}}$, total pyruvate dehydrogenase.

suckling rat intestine are 10-fold greater than levels in postweaned rats. In the preweaned rat (16 d of age) 3-hydroxybutyrate did not significantly inhibit glucose oxidation to $\mathrm{CO}_{2}$; however, inhibition by palmitate was observed. In postweaned adult rats both 3-hydroxybutyrate and palmitate significantly inhibited glucose oxidation to $\mathrm{CO}_{2}$ in intestine by 40 and $20 \%$, respectively. Exogenous 3-hydroxybutyrate inhibited pyruvate decarboxylation in suckling rat intestine by $15 \%$ (Table 3 ). In contrast, adult intestine pyruvate decarboxylation was inhibited by $35 \%$. Palmitate inhibited pyruvate decarboxylation in both suckling and adult intestine by approximately $25 \%$. Lactate production from glucose was not affected by the presence of palmitate of 3hydroxybutyrate in pre- or postweaned rat intestine.

\section{DISCUSSION}

The high rate of aerobic glycolysis in small intestine, which we have determined using a tissue slice assay system, is similar to values obtained using everted small intestine (13) and isolated mucosal cell $(13,18)$. A high ratio of glucose oxidation to lactate and glucose oxidation to $\mathrm{CO}_{2}$ under aerobic conditions is characteristic of adult small intestine, especially jejunum.

In contrast to the studies of Srivastav and Hubscher (21), we found that the rate of oxidation of glucose to lactate was comparable to the values found in the adult. Srivastav and Hubscher (21) used homogenates prepared from whole tissue and mucosal cells from newborn rats. The disruption of mucosal cells and loss of endogenous controls may limit the measured glycolytic activity.

We have shown that the decreased rate of glucose oxidation to $\mathrm{CO}_{2}$ by intestine of suckling rats is associated with a lower rate of pyruvate decarboxylation and a decrease in active pyruvate dehydrogenase. Changes in the activity of pyruvate dehydrogenase during suckling and weaning, periods of high and low fat intake, mediate changes in glucose oxidation to $\mathrm{CO}_{2}$. Is the decrease in pyruvate dehydrogenase activity and glucose oxidation to $\mathrm{CO}_{2}$ secondary to the high fat diet of suckling animals? Denton and Hughes (2) reported that rats placed on high fat diet for $6 \mathrm{~d}$ showed a rapid decrease in adipose tissue pyruvate dehydrogenase activity, which is primarily due to a decrease in the active form of the enzyme. Adipose tissue from rats on a high fat diet for 19-23 d had a significant decrease in total pyruvate dehydrogenase activity. These data are consistent with our own observation that the high fat diet provided naturally during the suckling period causes a decrease in total pyruvate dehydrogenase activity and active pyruvate dehydrogenase in small intestine.

Another possible influence on glucose metabolism during the suckling period is direct inhibition of the pyruvate dehydrogenase complex by serum ketones. During the suckling period, production of ketones by the liver is markedly elevated which results in an increase in serum ketone concentration (4). Windmueller and Spaeth (25) have reported that perfused adult rat jejunum oxidizes acetoacetate and 3-hydroxybutyrate and that the ketones are oxidized in preference to glucose and fatty acids. Other studies with perfused rat jejunum have shown that ketone bodies inhibit glucose oxidation to $\mathrm{CO}_{2}(9)$. Lamers and Hulsmann (17) reported that pyruvate decarboxylation in adult rat intestine mucosal cells is inhibited by $5 \mathrm{mM}$ DL-3-hydroxybutyrate.

We also found that glucose and pyruvate oxidation in adult intestine was inhibited by 3 -hydroxybutyrate but that oxidation by intestine from suckling pups was not altered by the presence of exogenous 3-hydroxybutyrate. This suggests that during the suckling period the oxidation of glucose and pyruvate is already maximally inhibited by endogenous ketones which are 10-fold greater in suckling than in postweaned rat intestine. Iemhoff $e t$ al. (13) reported that glucose oxidation to $\mathrm{CO}_{2}$ in isolated mucosal cells from a fasted adult rat was $1 / 3$ the rate seen in mucosal cells from fed adult rats. One can speculate that increased endogenous pools of ketones which are present in the starved state caused the inhibition of $\mathrm{CO}_{2}$ production. Hanson and Parson (9), using perfused adult jejunum reported that there is a significant decrease in the utilization of glucose by intestines of fasted rats $(48 \mathrm{~h})$ compared with fed rats. They noted a decrease in the oxidation of glucose in the jejunum of fasted compared with fed rats. In addition, the presence of ketones in the perfusate decreased the oxidation of glucose in the fed rat jejunum but completely inhibited the oxidation of glucose in the intestine of fasted rats. The presence of physiologic ketosis, which is seen in the fasted state and during the suckling period, alters intestinal glucose metabolism. The increased sensitivity of glucose oxidation to the presence of exogenous ketones in the intestine of fasted rats may be secondary to alterations in the reductionoxidation state of the intestine or the presence of endogenous ketones. Because lactate production from glucose was not affected by the presence of palmitate or 3-hydroxybutyrate in preor postweaned intestine, the concentration of palmitate and 3hydroxybutyrate used in these experiments does not affect gly- 
Table 3. Influence of 3-hydroxybutyrate and palmitate on glucose and pyruvate oxidation in developing rat intestine*

\begin{tabular}{|c|c|c|c|c|c|c|}
\hline \multirow[b]{2}{*}{ Substrate } & \multicolumn{3}{|c|}{ 16-d-old suckling } & \multicolumn{3}{|c|}{ Adult (postwean) } \\
\hline & Control & $+\mathrm{HB}^{* *}$ & $+\mathrm{C}_{16} * *$ & Control & $+\mathrm{HB}^{* *}$ & $+\mathrm{C}_{16} * *$ \\
\hline $\begin{array}{l}\text { Decarboxylation of } \\
\text { pyruvate }\end{array}$ & $\begin{array}{c}3.02 \pm 0.10 \\
(9)\end{array}$ & $\begin{array}{c}2.56 \pm 0.06 \dagger \\
(9)\end{array}$ & $\begin{array}{c}2.22 \pm 0.10 \dagger \\
(9)\end{array}$ & $\begin{array}{c}4.80 \pm 0.14 \\
(4)\end{array}$ & $\begin{array}{c}3.12 \pm 0.32 \dagger \\
(5)\end{array}$ & $\begin{array}{c}3.50 \pm 0.26 \dagger \\
(5)\end{array}$ \\
\hline $\begin{array}{l}\text { Oxidaton of glucose } \\
\text { to } \mathrm{CO}_{2}\end{array}$ & $\begin{array}{c}0.68 \pm 0.03 \\
(9)\end{array}$ & $\begin{array}{c}0.63 \pm 0.01 \ddagger \\
(4)\end{array}$ & $\begin{array}{c}0.54 \pm 0.02 \dagger \\
(9)\end{array}$ & $\begin{array}{l}1.26 \pm 0.08 \\
(12)\end{array}$ & $\begin{array}{c}0.69 \pm 0.04 \dagger \\
(8)\end{array}$ & $\begin{array}{c}0.86 \pm 0.11 \dagger \\
(8)\end{array}$ \\
\hline Lactate production & $\begin{array}{c}83.4 \pm 3.2 \\
(9)\end{array}$ & $89.0 \pm 1.8$ & $\begin{array}{c}69.6 \pm 2.2 \\
(5)\end{array}$ & $\begin{array}{c}76.6 \pm 4.6 \\
(8)\end{array}$ & $\begin{array}{c}69.0 \pm 4.0 \\
(4)\end{array}$ & $\begin{array}{c}79.2 \pm 6.2 \\
(4)\end{array}$ \\
\hline
\end{tabular}

* Data expressed as $\mathrm{nmol}$ substrate $\cdot \mathrm{mg}$ wet $\mathrm{wt}$ tissue $\mathrm{e}^{-1} \cdot \mathrm{h}^{-1}$. Values are expressed as mean $\pm \mathrm{SE}$ (number of experiments).

** $\mathrm{HB}, 3$-hydroxybutyrate $(4 \mathrm{mM})$ and $\mathrm{C}_{16}$, palmitate $(1 \mathrm{mM})$.

$\dagger$ Values are significantly different from control $(P<0.01)$.

$\ddagger$ Values are not significantly different from control $(P>0.2)$.

colytic activity or glucose uptake, which had been reported by Enser (5).

Assuming a steady-state equilibrium between endogenous 3hydroxybutyrate and acetoacetate, we determined that the intramitochondrial $\left[\mathrm{NAD}^{+}\right] /[\mathrm{NADH}]$ ratio is 8 -fold greater in the postweaned rat compared with the preweaned rat, which is consistent with the abrupt increase in the active form of pyruvate dehydrogenase. The inhibition of intestinal glucose and pyruvate oxidation of postweaned rats by exogenous 3-hydroxybutyrate may be secondary to alterations in the intramitochondrial pools of $[\mathrm{NADH}]$ and $\left[\mathrm{NAD}^{+}\right]$. A decrease in the $\left[\mathrm{NAD}^{+}\right] /[\mathrm{NADH}]$ ratio with the addition of exogenous 3-hydroxybutyrate could result from a shift in the equilibrium of 3-hydroxybutyrate dehydrogenase to acetoacetate. Hansford and Cohen (8), utilizing isolated rat heart mitochondria pretreated with inhibitors of oxidative phosphorylation, was able to alter the intramitochondrial $\left[\mathrm{NAD}^{+}\right] /[\mathrm{NADH}]$ ratio by 12 -fold with the addition of acetoacetate and 3-hydroxybutyrate. The addition of acetoacetate to a mitochondrial suspension resulted in an increase in active pyruvate dehydrogenase and the activation was reversed with the subsequent addition of 3-hydroxybutyrate. The oxidation of ketones, which increases the production of $\mathrm{NADH}$, would also decrease the $\left[\mathrm{NAD}^{+}\right] /[\mathrm{NADH}]$ ratio.

We have not determined in the developing intestine if the presence of high concentrations of endogenous ketones during the suckling period causes a decrease in the intramitochondrial $\left[\mathrm{NAD}^{+}\right] /[\mathrm{NADH}]$ ratio or whether the intramitochondrial $\left[\mathrm{NAD}^{+}\right] /[\mathrm{NADH}]$ ratio is physiologically low during this period. Developmental changes in enzyme systems that use NADH as a substrate such as $\alpha$-glycerophosphate dehydrogenase may also alter intramitochondrial [NADH]/[NAD ${ }^{+}$. Further studies determining the rate of ketone oxidation and the energy requirements by suckling rat intestine are now in progress.

In contrast to the influence of 3-hydroxybutyrate, the inhibition of intestinal glucose and pyruvate oxidation by exogenous palmitate was constant throughout the suckling and weaning periods, suggesting a different inhibitory mechanism for fatty acids. Olson et al. (19) reported direct inhibition of the active pyruvate dehydrogenase complex by acyl-CoA esters.

Metabolic studies using tissue slices reflect activity of different cell types. Changes in cell population during development can also cause profound changes in tissue metabolism. Iemhoff and Hulsmann (14) found that the $\mathrm{CO}_{2}$ production from pyruvate by mitochondria of villous cells was much greater than by crypt cells. Because whole tissue slices were used in these experiments, developmental changes in villous and crypt cell populations at the time of weaning could alter glucose metabolism in intestine. Koldovsky et al. (16) reported an increase in cell turnover in intestine at the time of weaning. Others have shown that there is a marked increase in intestinal weight at the time of weaning with an associated increase in the depth of crypt columns (10, $26)$. There is the possibility that changes in cell population at this period could affect the results reported.

\section{REFERENCES AND NOTES}

1. Barker, S and Summerson, W - Colorimetric determination of lactic acid in biological material. J. Biol. Chem., 138: 535 (1941).

2. Denton, R. M. and Hughes, W. A.: Pyruvate dehydrogenase and the hormonal regulation of fat synthesis in mammalian tissues. Int. J. Biochem., 9: 545 (1978).

3. Dobiasova, M. Hahn, $P_{\text {.n }}$ and Koldovsky, O.: Fatty acid composition in developing rat. Biochem. Biophys. Acta, 84:538 (1964)

4. Drahota, Z., Hahn, P., Klieninzeller, A., and Kostolanska, A.: Acetoacetate formation by liver slices from adult and infant rats. Biochem. J., 93: 61 (1964).

5. Enser, M.: Fatty acids and intestinal metabolism. Biochem. J., 93: 290 (1964)

6. Hahn, P. and Koldovsky. O.: Utilization of Nutrients During Postnatal Development. p. 17 (Pergamon Press Ltd.. Oxford, 1966).

7. Hahn, P. and Skala, J.: The development of some enzyme activities in the gut of the rat. Biol. Neonate, 18:433 (1971).

8. Hansford. R. G. and Cohen, L.: Relative importance of pyruvate dehydrogenase interconversion and feed-back inhibition in the effect of fatty acids on pyruvate oxidation by rat heart mitochondria. Arch. Biochem. Biophys., 191: $65(1978)$

9. Hanson, P. and Parson, D.: Factors affecting the utilization of ketone bodies and other substrates by rat jejunum: effects of fasting and of diabetes. $J$. Physiol., 278: 55 (1978).

10. Herbst, J. and Sunshine, P.: Postnatal development of the small intestine of the rat. Pediatr. Res., 3: 2733 (1969).

11. Hohorst, Hans-Jurgen: $L_{-}(+)$- Lactate determination with lactic dehydrogenase and DPN. In: H. U. Bergmeyer: Methods of Enzymatic Analysis. p. 266-270 (Academic Press, New York, 1965).

12. Hulsmann, W. C.: Preferential oxidation of fatty acids by rat small intestine. FEBS Lett. 17: 35 (1971).

13. Iemhoff, W.. Van Den Berg, J., DePijper, A., and Hulsmann, W. C.: Metabolic aspects of isolated cells from rat small intestinal epithelium. Biochem. Biophys. Acta, 215: 229 (1970).

14. Iemhoff. W. and Hulsmann, W.: Development of mitochondrial enzyme activities in rat-small-intestinal epithelium. Eur. J. Biochem., 23: 429 (1971).

15. Kerby, A. L., Randle, P., Cooper, R., Whitehouse, S., Park, H., and Denton, R.: Regulation of pyruvate dehydrogenase in rat heart. Biochem. J., I54: $327(1976)$.

16. Koldovsky, O., Sunshine, P., and Kretchmer, W.: Cellular migration of intestinal epithelia in suckling and weaned rats. Nature, 212:1389 (1966).

17. Lamers, J. and Hulsmann, W.: The effects of fatty acids on oxidation decarboxylation of pyruvate in rat small intestine. Biochem. Biophys. Acta, 343: 215 (1974).

18. Neptune, E.: Respirations and oxidation of various substrates by ileum in vitro. Am. J. Physiol., 209(2): 329 (1965).

19. Olson. M., Dennis. S., Routh, $C$. and Debuysere, $M$ : The regulation of pyruvate dehydrogenase by fatty acids in isolated rabbit heart mitochondria. Arch. Biochim. Biophys., 187: 121 (1978).

20. Page, M.. Krebs, H., and Williamson, D.: Activities of enzymes of ketone-body utilization in brain and other tissues of suckling rats. Biochem. J., 121:49 (1971).

21. Srivastav, L. and Hubscher, G.: The effect of age on glycolytic and hexokinase activities in the mucosa of rat small intestine. Biochem. J., 110:607 (1968).

22. Taylor, S., Mukherjee, C., and Jungas, R.: Regulation of pyruvate dehydrogenase in isolated rat liver mitochondria. J. Biol. Chem., 250: 2028 (1976)

23. Viktora, J., Fodor. J., Grafnetter, D., Hahn, P., Koldovsky, O., and Lojda, Z.: Studies of certain biochemical indices of fat metabolism during the ontogenesis of the rat. Cs. Fysiol., 9:63 (1960).

24. Williamson, J. R. and Corkey, B.: Assays of intermediates of the citric acid cycle and related compounds by fluorometric enzyme methods. Methods Enzymol.. 13: 424 (1969).

25. Windmueller. H. and Spaeth. A.: Identification of ketone bodies and glutamine as the major respiratory fuels in vivo for postabsorptive rat small intestine. J. Biol. Chem., 253:69 (1978).

26. Yen. K-Y. and Moog. F.: Influence of the thyroid and adrenal glands on the 
growth of the intestine of the suckling rat and on the development of intestinal alkaline phosphatase and disaccharidase activities. J. Exp. Zool., 200: 337 (1977).

27. Charles River Labs, Cambridge, MA

28. Brinkman Instruments, Westbury, NY

29. Kontes Glass Col, Vineland, NJ.

30. New England Nuclcar, Boston, MA.

31. Beckman Instrument Co.. Palo Alto, CA

32. The present address of Dr. Warshaw is: Department of Pediatrics, University of Texas, Southwestern Medical School, 5323 Harry Hines Blvd., Dallas, Texas 75235 .

33. Requests for reprints should be addressed to: Dr Robert E Kimura, Department of Pediatrics. University of Utah School of Medicine, 50 N. Medical Dr., Salt Lake City, Utah 84132.

34. This research was supported by NIH grant no. 1-R23 HD 16908-01.

35. Received for publication December 30,1982

36. Accepted for publication September 22, 1983.

\title{
Effects of Meclofenamate on Pulmonary Vascular Resistance Correlate with Postnatal Age in Young Piglets
}

\author{
GREGORY J. REDDING, ${ }^{(26)}$ IVAN MCMURTRY, AND JOHN T. REEVES \\ Cardiovascular Pulmonary Research Laboratory, University of Colorado Health Sciences Center, \\ Denver, Colorado, USA
}

\begin{abstract}
Summary
We administered sodium meclofenamate, a prostaglandin synthetase inhibitor, to 15 piglets (ages 5-70 d) to test the hypothesis that endogenous prostaglandin pulmonary vasodilators influence total pulmonary resistance under both normoxic and hypoxic conditions. No significant differences in hemodynamic measurements were found between the control group and drug-treated animals more than 12-d-old. When six experimental animals less than $12 \mathrm{~d}$ of age were compared with six age-matched controls, meclofenamate produced a small but significant increase in mean pulmonary artery pressure $(110 \pm 9$ versus $97 \pm 10 \%, P<0.05)$ and total pulmonary resistance $(135 \pm 23$ versus $102 \pm 12 \%, P$ $<0.03$ ). The magnitude of the change in total pulmonary resistance produced by $2 \mathrm{mg} / \mathrm{kg}$ of meclofenamate during normoxia correlated inversely with postnatal age $(r=0.83, P<0.01)$. Individual changes in pulmonary hemodynamics produced by acute hypoxia after meclofenamate treatment were the same as pretreatment values and were similar in both young and older animals.
\end{abstract}

Prostaglandin compounds produce either vasoconstriction of dilation of the pulmonary circulation when administered to adult and neonatal animals $(5,7,11,17,18,20)$. The importance of endogenous prostaglandin production in the regulation of pulmonary vascular tone under normoxic and hypoxic conditions is less clear as data from previously reported studies are somewhat conflicting. For example, Tyler et al. (22) found that pulmonary vascular resistance increased after inhibition of prostaglandin production by indomethacin during both normoxia and acute exposure to hypoxia in newborn goats. Lock et al. (12) found an increase in pulmonary vascular tone under normoxic conditions within minutes after indomethacin was administered intravenously but not when given orally to 2-4-wk-old lambs. In contrast, Weir et al. (24) found no changes in pulmonary artery pressure during normoxia after intravenous administration of meclofenamate to 2-4-mo-old calves. We administered sodium meclofenamate, a prostaglandin synthetase inhibitor (3), to newborn piglets to further test the hypothesis that endogenous prostaglandin pulmonary vasodilators influence total pulmonary vascular resistance in newborns under both normoxic and hypoxic conditions. Our data indicate that total pulmonary resistance increased after meclofenamate treatment under normoxic conditions in animals less than 12-d-old and that this effect diminished with increasing postnatal age. In addition, we found that inhibition of prostaglandin synthesis had no effect upon hypoxic pulmonary vasoconstriction in piglets.

\section{MATERIALS AND METHODS}

Animal preparation. Thirty-three piglets, aged 5-88 d and weighing $1.75-25 \mathrm{~kg}$, were anesthetized with intravenous sodium pentobarbital $(15 \mathrm{mg} / \mathrm{kg})$, heparinized, and intubated. Each animal was mechanically ventilated using a Harvard small animal ventilator, adjusted to deliver a tidal volume of $15 \mathrm{cc} / \mathrm{kg}$ at a rate of 20-30 breath/min in order to maintain $\mathrm{PaCO}_{2} 37 \pm 5 \mathrm{~mm} \mathrm{Hg}$; positive end-expiratory pressure was maintained at $2 \mathrm{~cm} \mathrm{H}_{2} \mathrm{O}$. Arterial oxygen tensions were maintained at approximately 60 $\mathrm{mm} \mathrm{Hg}$ or more during normoxic conditions by supplementing inspired room air with $30 \% \mathrm{FiO}_{2}$ when necessary. Body temperature was monitored with a rectal probe (Yellow Springs Model 333) and was maintained at $38.5 \pm 0.7^{\circ} \mathrm{C}$ using heating lamps to approximate the temperatures of awake uninstrumented piglets.

A polyethylene catheter was placed in the descending aorta via the left internal carotid artery for blood pressure recordings and arterial blood sampling. A second catheter was inserted into the superior vena cava via the left external jugular vein for injections of green dye and drug administration. A double-lumen balloontipped catheter was placed in the left branch of the pulmonary artery via the right external jugular vein under fluoroscopy to measure pulmonary artery pressure. Inflation of the balloon frequently produced pulmonary hypertension or systemic hypotension, and consequently, pulmonary capillary wedge pressure was measured during only 11 of 27 experiments. Heart rate and 